\title{
The Effect of Beetroot (Beta Vulgaris) on Hemoglobin Levels and Vo2max Atlet Value
}

\author{
Sanrebayu ${ }^{1 *}$, Aminuddin Syam $^{1}$, Wahiduddin $^{2}$, Safruddin $^{3}$ \\ ${ }^{1}$ Nutrition Department, Faculty of Public Health, Hasanuddin University, Indonesia \\ ${ }^{2}$ Epidemiology Department, Faculty of Public Health, Hasanuddin University, Indonesia \\ ${ }^{3}$ Nursing Department, Panrita Husada Health Sciences College Bulukumba, Indonesia \\ *Corresponding Author \\ Sanrebayu
}

\section{Article History}

Received: 25.01 .2020

Accepted: 19.02 .2020

Published: 21.02.2020

\begin{abstract}
This study aims to determine the effect of beetroot juice on hemoglobin levels and the VO2Max value of an athlete. This research is an experimental study using a true experimental design with a pretest-posttest control group design approach. This study used 36 badminton athletes divided into 3 groups. The results showed that there were significant differences in hemoglobin levels in badminton athletes after consuming beetroot juice, the $200 \mathrm{ml}$ beetroot juice group ( $\mathrm{p}=0.001)$, the $300 \mathrm{ml}$ beetroot juice group $(\mathrm{p}=0.002)$. There was a difference in the levels of Hemoglobin in badminton athletes after treatment between consuming $200 \mathrm{ml}$ beetroot juice and a group consuming $300 \mathrm{ml}$ beetroot juice but not significant $(\mathrm{p}=0.744>\mathrm{p}=0.05)$. There were significant differences in VO2Max values after consumption of beetroot juice in the $300 \mathrm{ml}$ group $(\mathrm{p}=0,000)$, but there were no significant differences in VO2Max values in the control group $(\mathrm{p}=0.007)$ and the $200 \mathrm{ml}$ group $(\mathrm{p}=0.007)$. There was a significant difference in the value of VO2Max badminton athletes between the group consuming $200 \mathrm{ml}$ beetroot juice and the group consuming $300 \mathrm{ml}$ beetroot juice after treatment $(\mathrm{p}=0.031<\mathrm{p}=0.005)$. Beetroot juice can be highly recommended for athletes to maintain stamina in optimal conditions.
\end{abstract}

Keywords: Beetroot Juice, Hemoglobin Level, Vo2max Value, Athlete.

\section{INTRODUCTION}

An athlete is required to always have the stamina that does not get tired. But in reality, not a few athletes have decreased stamina during the competition in a short amount of time so that this can reduce the performance of an athlete. Indicators of decreased performance can be seen from the level of physical fitness of athletes when competing. Quantitatively the athlete's physical fitness can be measured through cardiorespiratory endurance during exercise activities [1].

Cardiorespiratory resistance is the ability of the heart, lungs, and blood vessels to function optimally at work when taking maximum oxygen (VO2Max) and channeling it throughout the body, especially in active tissues so that it can be used for metabolic processes. Measuring cardio respiration endurance can be done by measuring maximum oxygen consumption. VO2Max is the maximum amount of oxygen that can be consumed during intense physical activity until fatigue occurs. VO2Max measurement can be used to analyze an athlete's stamina level [2- 4].

Cardiorespiratory endurance in men reaches its peak at the age of 18-25 years together with the peak of muscle mass growth [5]. Cardiorespiratory endurance in males is said to be good if the VO2Max score is $44-52.9 \mathrm{ml} / \mathrm{kg} / \mathrm{minute}$ [6]. Several studies have shown that the cardio respiration endurance of a young athlete in Indonesia is not good enough. Research conducted by Permadi, 2017, a survey of VO2Max endurance in badminton athletes shows results that are categorized as moderate with an average VO2Max value of $38.49 \mathrm{ml} / \mathrm{kg} /$ minute. The percentage of the endurance of each athlete is $20 \%$ good category, $30 \%$ medium category, $20 \%$ less category, and $30 \%$ with very less category.

Copyright @ 2020: This is an open-access article distributed under the terms of the Creative Commons Attribution license which permits unrestricted use, distribution, and reproduction in any medium for non commercial use (NonCommercial, or CC-BY-NC) provided the original author and source are credited. 
Decreased cardiorespiratory endurance (VO2Max) will disrupt aerobic capacity, especially during physical activity or exercise with long duration so that it will be easily tired due to reduced oxygen supply in the muscles and the formation of lactic acid which can cause or cause fatigue in the muscles [7].

One factor that can affect the level of physical fitness of a person is Hb levels. To increase Hb levels, more iron consumption is needed to form blood $\mathrm{Hb}$. There are several factors that support the formation of $\mathrm{Hb}$ by iron, one of which is zinc which has the role of forming transferrin as a means of transporting iron to where it is needed [8]. Low levels of $\mathrm{Hb}$ a person has a bad impact on one's physical fitness because the activities needed enough $\mathrm{Hb}$ to bind $\mathrm{O} 2$ in the air. Therefore, iron and zinc are important nutrients for hemoglobin and physical fitness.

Hemoglobin has an important role in cardiorespiratory endurance, namely as a carrier of oxygen from the lungs and then distributed throughout the body's tissues. Hemoglobin has a role as a sender of oxygen to the entire network so that it affects the value of VO2Max [9, 10]. Research conducted by Huldani states that in the group that has normal $\mathrm{Hb}$ on average has a VO2Max value of $47.59 \mathrm{ml} / \mathrm{kg} / \mathrm{min}$, higher than the average VO2Max value in the group that has a low hemoglobin level of $37.84 \mathrm{ml} / \mathrm{kg} /$ minute [11]. One of the substances that can optimize VO2Max levels is the nitrate content found in food ingredients. Beet tubers are one food source that has a high nitrate content [12].

Utilization of beetroot (Beta vulgaris) in sports is still very few and even very rarely an athlete knows about the benefits of beetroot. One of the potential or benefits of beetroot that has not been utilized in the field of sports nutrition is beetroot able to increase the stamina of an athlete with an indication that beetroot can increase the VO2Max of an athlete with nitrate content which biologically affects the regulator of $\mathrm{O} 2$ utilization by muscle contractors so that the distribution of $\mathrm{O} 2$ is in accordance with muscle needs [13].

Beet tubers are one food ingredient that contains nitrates. Beets derived from beet plants (Beta vulgaris) have a distinctive purplish-red color due to the presence of betalain pigments. Several studies have proven the effect of beet tubers on pulmonary oxygen uptake (VO2). Research conducted in 2010 in the United Kingdom which stated that consumption of inorganic nitrates $(5.1 \mathrm{mmol}$ nitrate/day) in the form of $500 \mathrm{ml}$ beetroot juice for 6 days can reduce pulmonary oxygen uptake (VO2) in heavy intensity exercise so that it can delay fatigue time in an athlete [13].

Research conducted by Bailey et al. [15] states that beetroot can increase VO2Max in the subject of 8 healthy men (not athletes) aged 19-38 years after consuming $500 \mathrm{ml}$ of beetroot/day for 6 days. Research conducted by Fillah Fithra Dieny et al stated that there was no significant effect on beetroot juice administration on VO2Max and Hb levels, but the increase in VO2Max in the group consuming $300 \mathrm{ml}$ beet tubers was greater than the group consuming $200 \mathrm{ml}$ beet tubers [4]. in addition to the nitrate content found in beetroot, beetroot also contains vitamins and minerals which are iron, folic acid and vitamin $C$ which can increase an athlete's Hb level [16, 17]. Research conducted by A.M Jones says supplementing nitrate or beetroot juice can improve sports performance in moderate caliber athletes and individuals among the elite population [18].

Based on the background description, researchers are interested in examining the effect of beetroot juice on hemoglobin levels and the VO2Max value of an athlete. This research was conducted on badminton athletes.

\section{METHODS}

\section{Research design}

This research is an experimental study using a true experimental design with a pretest-posttest control group design approach. This research was divided into 3 research groups namely treatment group I, treatment group II, and placebo. Treatment group, I was given $300 \mathrm{ml}$ beetroot juice and treatment group II was given $200 \mathrm{ml}$ beetroot juice. The independent variable in this study is the administration of beetroot juice and the dependent variable in this study is the hemoglobin level and VO2Max value.

The research location used is the Badminton Sports Hall of the Faculty of Sport Science UNM. Researchers chose the UNM Sports Faculty Badminton GOR as a research location on the grounds that the UNM Sports Badminton Faculty GOR as a place for researchers usually practiced badminton and there were many students who were active and practicing regularly.

\section{Population and Sample}

The population in this study were all students of badminton athletes who are members of BKMF Badminton FIK UNM. Samples to be used in this study were 30 athletes, which were divided into three groups, namely the $300 \mathrm{ml}$ treatment group, the $200 \mathrm{ml}$ treatment group, and the control group. This study used 36 badminton athletes who were divided into 3 groups. 


\section{Data Analysis}

Data analysis using SPSS for windows software program to see the effect of beetroot juice on hemoglobin levels and VO2Max values of badminton athletes. Univariate analysis Bivariate analysis was used to analyze differences in $\mathrm{Hb}$ levels and post VO2Max values, increase in Hb levels and VO2Max values, and confounding variables between the three groups. Multivariate analysis uses a multiple linear regression test to analyze confounding variables that most influence the increase in $\mathrm{Hb}$ levels and VO2Max values. After that, ANCOVA Test was performed to see the effect of beetroot juice administration after being controlled with confounding variables [19].

\section{RESUlts}

Table-1: Characteristics of Research Subjects in All Three Groups

\begin{tabular}{|c|c|c|c|c|c|c|c|c|c|c|c|c|c|}
\hline \multirow[t]{2}{*}{ Subject Description } & \multicolumn{4}{|c|}{ Beetroot Juice $300(n=12)$} & \multicolumn{4}{|c|}{ Beetroot Juice $200(n=12)$} & \multicolumn{4}{|c|}{ Control $(n=12)$} & \multirow[t]{2}{*}{$\mathbf{p}$} \\
\hline & Mean & SD & Min & Max & Mean & SD & Min & Max & Mean & SD & Min & Max & \\
\hline Age (years) & 20,08 & 2,11 & 18 & 25 & 19,50 & 1,24 & 18 & 21 & 19,58 & 0,90 & 18 & 21 & $0.915 * *$ \\
\hline Body Weight & 59,63 & 10,70 & 39 & 73,6 & 62,09 & 6,09 & 54 & 72,7 & 57,53 & 4,67 & 50 & 63,1 & $0.409 * *$ \\
\hline Height & 166,92 & 6,83 & 151 & 176 & 166,58 & 5,14 & 160 & 180 & 165,75 & 5,03 & 153 & 171 & $0.793 * *$ \\
\hline IMT & 21,21 & 2,64 & 17,1 & 25,9 & 22,42 & 2,63 & 19 & 26,7 & 20,93 & 2,43 & 18 & 27 & $0.331 *$ \\
\hline
\end{tabular}

\section{Analysis of Hemoglobin (Hb) Levels in Badminton Athletes}

The results of hemoglobin analysis in badminton athletes BKMF FIK UNM before and after treatment can be seen in the following table:

Table-2: Results of Hemoglobin Analysis in Badminton Athletes Before and After Treatment

\begin{tabular}{|c|c|c|c|c|c|c|c|c|}
\hline \multirow{2}{*}{\multicolumn{2}{|c|}{ Group }} & \multicolumn{2}{|c|}{ Beetroot Juice $300(n=12)$} & \multicolumn{2}{|c|}{ Beetroot Juice $200(n=12)$} & \multicolumn{3}{|c|}{ Control $(n=12)$} \\
\hline & & Mean & SD & Mean & SD & Mean & SD & $P * *$ \\
\hline $\mathrm{Hb}$ & Pre test & 12,71 & 1,62 & 12,65 & 1,21 & 11,41 & 1,90 & $0.096 * *$ \\
\hline & Hari Ke-7 & 14,03 & 1,54 & 13,65 & 1,31 & 12,35 & 1,29 & $0,014 * *$ \\
\hline & Hari Ke-16 & 14,76 & 1,12 & 14,92 & 1,22 & 13,14 & 1,54 & $0,003 * *$ \\
\hline & $P^{*}$ & $0,002 *$ & & $0,001 *$ & & & $001 *$ & \\
\hline
\end{tabular}

*Repeated ANOVA

**One-Way ANOVA

The control group, the $200 \mathrm{ml}$ treatment group and the $300 \mathrm{ml}$ treatment group each consisted of 12 respondents. Differences in the effect of beetroot juice administration on $\mathrm{Hb}$ levels, then $\mathrm{Hb}$ levels were measured three times, namely before treatment, one week after treatment and on the 16th day after 15 treatment days. Before the treatment of the average $\mathrm{Hb}$ levels of the control group was $11.41 \pm 1.90 \mathrm{gr} / \mathrm{dl}$, the treatment group was $200 \mathrm{ml} 12.65 \pm 1.21 \mathrm{gr} / \mathrm{dl}$ and for the treatment group $300 \mathrm{ml} 12.71 \pm 1.62 \mathrm{gr} / \mathrm{dl}$. After treatment, the average Hb levels in the three groups experienced an increase of $13.14 \pm 1.54 \mathrm{gr} / \mathrm{dl}$ in the control group, $14.92 \pm 1.22 \mathrm{gr} / \mathrm{dl}$ in the $200 \mathrm{ml}$ treatment group and $14.76 \pm 1.12$ $\mathrm{gr} / \mathrm{dl}$ in the $300 \mathrm{ml}$ treatment group.

Repeated ANOVA statistical test results $(\alpha=0.05)$ there were significant differences in the increase in Hb levels before and after treatment in the three groups. It can be interpreted that both the treatment group and the control group both experienced significant increases in $\mathrm{Hb}$ levels before and after treatment $(\mathrm{p}<0.05)$. However, the mean increase in $\mathrm{Hb}$ in the $300 \mathrm{ml}$ treatment group $(14.74 \pm 1.12 \mathrm{gr} / \mathrm{dl})$, the $200 \mathrm{ml}$ group $(14.76 \pm 1.22 \mathrm{gr} / \mathrm{dl})$ was higher than the control group $(13.14 \pm 1,54 \mathrm{gr} / \mathrm{dl})$. One-way ANOVA test results showed no significant difference in hemoglobin levels in the three groups after the intervention for 7 days with a value of $p=0.014>0.05$ but after 15 days of intervention, there was a significant difference in hemoglobin levels in the three groups in the name $p$-value $=0.003<0.05$.

Table-3: Results of Analysis of Hemoglobin Levels in the $300 \mathrm{ml}$ Group and $200 \mathrm{ml}$ Group

\begin{tabular}{|l|l|l|l|l|l|l|}
\hline \multirow{2}{*}{ Group } & \multicolumn{3}{|l|}{ Beetroot Juice 300 (n = 12) } & \multicolumn{2}{l|}{$\begin{array}{l}\text { Beetroot Juice 200 }(\mathbf{n}= \\
\text { 12) }\end{array}$} \\
\cline { 2 - 7 } \multicolumn{2}{|l|}{} & Mean & SD & Mean & SD & p \\
\hline $\mathrm{Hb}$ & Pre Test & 12,708 & 1,6155 & 12,65 & 1,2072 & $0.921^{*}$ \\
\hline & Hari Ke-7 & 14,033 & 1,5412 & 13,65 & 1,3063 & $0.518^{*}$ \\
\hline & Hari Ke-16 & 14,758 & 1,1212 & 14,917 & 1,2187 & $0.744^{*}$ \\
\hline
\end{tabular}

*Independent Samples T-test 
Based on Table 3 the results of the analysis show that there is no significant difference in the Hb pre-test levels in the $200 \mathrm{ml}$ group and the $300 \mathrm{ml}$ group with a p-value $=0.921>0.05$. On the seventh day of the treatment also there was no significant difference in $\mathrm{Hb}$ levels between the two treatment groups with a value of $\mathrm{p}=0.518>0.005$. On the 15 th day after treatment there was also no significant difference between the $200 \mathrm{ml}$ treatment group and the $300 \mathrm{ml}$ treatment group where the $\mathrm{p}$ value $=0.744>0.05$.

To see more clearly the difference between the mean $\mathrm{Hb}$ levels before and after treatment in each treatment group and the control group can be seen in Figure 1.

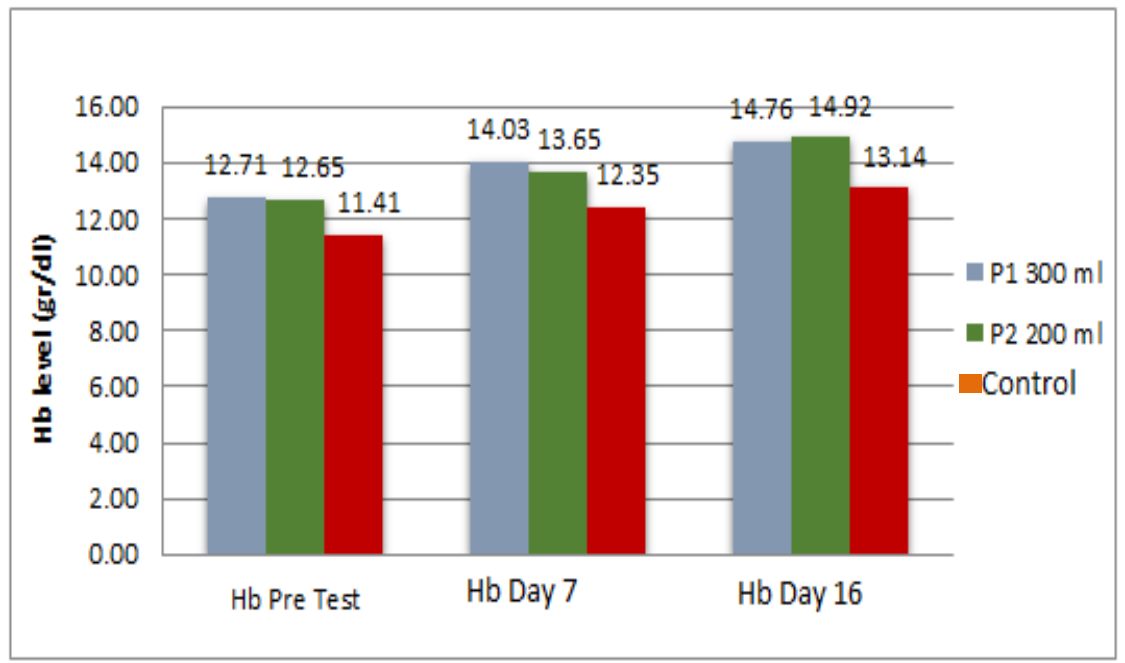

Fig-1: Mean Changes in Hemoglobin Levels before and After Treatment

\section{Analysis of VO2Max Value for Badminton Athletes}

The results of the analysis of VO2Max values in badminton athletes BKMF FIK UNM before and after treatment can be seen in the following table:

Table-4: Results of VO2Max Value Analysis of Badminton Athletes Before and After Treatment

\begin{tabular}{|c|c|c|c|c|c|c|c|c|}
\hline \multirow{2}{*}{\multicolumn{2}{|c|}{ Group }} & \multicolumn{2}{|c|}{ Beetroot Juice $300(n=12)$} & \multicolumn{2}{|c|}{ Beetroot Juice $200(n=12)$} & \multicolumn{3}{|c|}{ Control $(n=12)$} \\
\hline & & Mean & SD & Mean & SD & Mean & $\mathrm{SD}$ & $P^{* *}$ \\
\hline VO2Max & Pre test & 43,69 & 5,92 & 39,85 & 6,94 & 38,53 & 7,21 & $0,164 * *$ \\
\hline & Post test & 49,39 & 6,17 & 43,57 & 6,28 & 41,28 & 5,90 & $0,008 * *$ \\
\hline & $P^{*}$ & $0,000^{*}$ & & \multicolumn{2}{|c|}{$0,007 *$} & \multicolumn{3}{|c|}{$0,007^{*}$} \\
\hline
\end{tabular}

*Paired T-test

** One-Way ANOVA

Based on Table 4. shows the VO2Max value before treatment in the control group is $38.53 \pm 7.21 \mathrm{ml} / \mathrm{kg} / \mathrm{min}$, the $200 \mathrm{ml}$ group is $39.85 \pm 6.94 \mathrm{ml} / \mathrm{kg} / \mathrm{min}$ and the $300 \mathrm{ml}$ group is $43.69 \pm 5.92 \mathrm{ml} / \mathrm{kg} / \mathrm{minute}$. After treatment, each group experienced an increase in VO2Max value to $41.26 \pm 5.90 \mathrm{ml} / \mathrm{kg} / \mathrm{min}$ in the control group, $43.57 \pm 6.26 \mathrm{ml} / \mathrm{kg} / \mathrm{min}$ in the $200 \mathrm{ml}$ group and the $300 \mathrm{ml}$ group the VO2Max value is increased to $49.39 \pm 6.17 \mathrm{ml} / \mathrm{kg} / \mathrm{min}$.

Based on Table 4. the results of the paired T-test showed that there was no significant increase in VO2Max values in the control group and in the $200 \mathrm{ml}$ group where the $\mathrm{p}$-value $=0.007>0.05$. However, the $300 \mathrm{ml}$ group experienced a significant increase in VO2Max with a value of $\mathrm{p}=0,000<0.05$. One-way ANOVA test results showed no significant difference in VO2Max values in the three groups after consumption of beetroot juice where $\mathrm{p}=0.008>0.05$.

Table-5: Results of Analysis of VO2Max Values in the $300 \mathrm{ml}$ Group and $200 \mathrm{ml}$ Group

\begin{tabular}{|l|l|l|l|l|l|l|}
\hline \multicolumn{2}{|c}{ Group } & \multicolumn{2}{|l|}{ Beetroot Juice 300 (n = 12) } & \multicolumn{2}{l|}{ Beetroot Juice 200 (n = 12) } & \\
\cline { 3 - 7 } \multicolumn{2}{|c|}{} & Mean & SD & Mean & SD & p \\
\hline VO2Max & Pre Test & 43,692 & 5,918 & 39,85 & 6,9426 & $0,159 *$ \\
\hline & Post Test & 49,392 & 6,1654 & 43,567 & 6,2564 & $0,031^{*}$ \\
\hline
\end{tabular}

*Independent Samples T Test 
Based on Table 5 the results of the analysis show that there is no significant difference in VO2Max values between the $200 \mathrm{ml}$ group and the $300 \mathrm{ml}$ group before treatment where the $\mathrm{p}$-value $=0.159>0.05$. But after giving treatment there was a significant difference between the two groups with a value of $\mathrm{p}=0.031<0.05$.

To see more clearly the difference in mean VO2Max values before and after treatment in each group in Figure 4.2. Based on Table 4.5 the results of the analysis show that there is no significant difference in VO2Max values between the $200 \mathrm{ml}$ group and the $300 \mathrm{ml}$ group before treatment where the $\mathrm{p}$ value $=0.159>0.05$. But after giving treatment there was a significant difference between the two groups with a value of $p=0.031<0.05$.

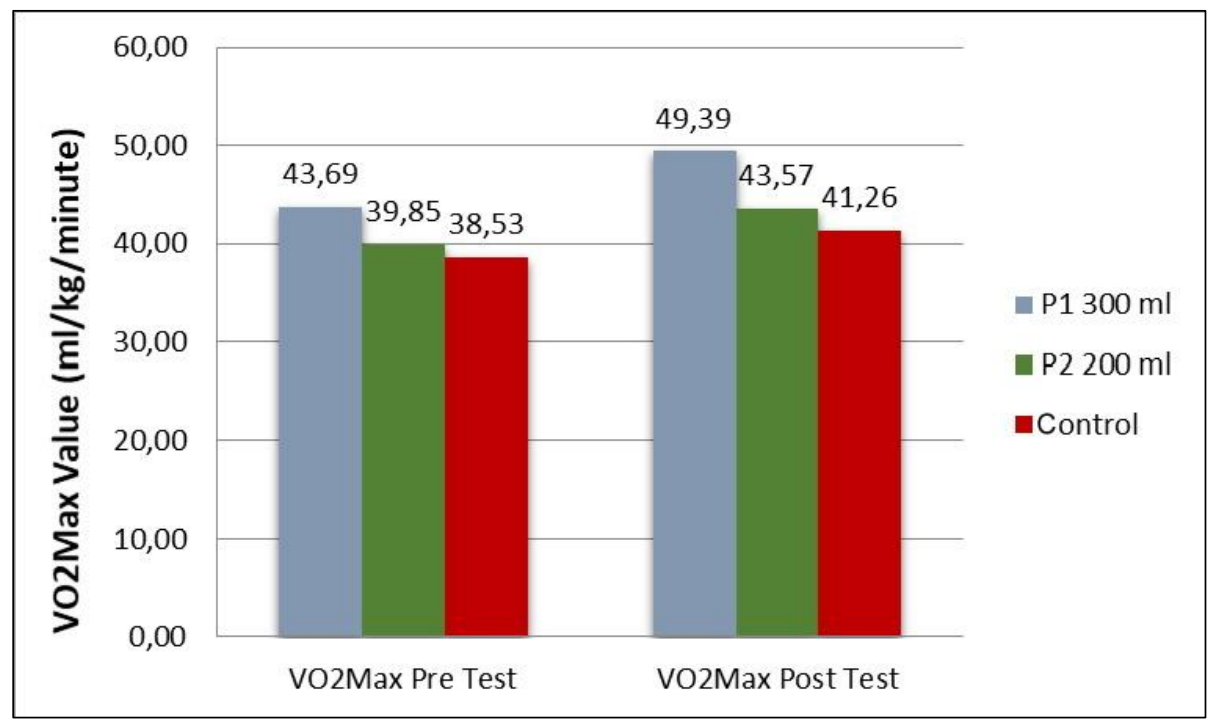

Fig-2: Mean Change in VO2Max Value before and After Treatment

Figure 2 shows that after the mean treatment of VO2Max the value of badminton athletes increased in all three groups, but the highest increase occurred in the group consuming $300 \mathrm{ml}$ of beetroot juice whose pre-test VO2Max value was $43.69 \pm 6.17 \mathrm{ml} / \mathrm{kg} /$ minute increasing to $49.39 \pm 6.17 \mathrm{ml} / \mathrm{kg} /$ minute and the mean increase in VO2Max values was lowest in the control group, which was VO2Max pre-test at $38.53 \pm 7.21 \mathrm{ml} / \mathrm{kg} /$ minute and in the post-test it increased to $41,26 \pm 5.90 \mathrm{ml} / \mathrm{kg} / \mathrm{minute}$.

\section{Analysis of Confounding Variables}

Table-6: Overview of Confounding Variables during Interventions in the Control and Treatment Group

\begin{tabular}{|c|c|c|c|c|c|c|c|c|c|c|c|c|c|}
\hline \multirow{2}{*}{$\begin{array}{c}\text { Subject } \\
\text { Description }\end{array}$} & \multicolumn{4}{|c|}{ Beetroot Juice $300(n=12)$} & \multicolumn{4}{|c|}{ Beetroot Juice $200(\mathrm{n}=12)$} & \multicolumn{4}{|c|}{ Control $(n=12)$} & \multirow[t]{2}{*}{ p } \\
\hline & Mean & SD & Min & Max & Mean & SD & Min & Max & Mean & SD & Min & Max & \\
\hline calories & 1485,92 & 184,89 & 1143 & 1697 & 1527,58 & 77,26 & 1433 & 1668 & 1499,83 & 89,68 & 1325 & 1646 & $0.717^{*}$ \\
\hline energy & 2104,17 & 610,09 & 1171 & 3372 & 1860,83 & 367,22 & 1293 & 2594 & 2047,92 & 295,07 & 1271 & 2420 & $0.184 * *$ \\
\hline carbohydrate & 263,16 & 79,09 & 161,1 & 459,08 & 225,48 & 46,97 & 149,2 & 281,6 & 2535,09 & 8116,41 & 115,89 & 28308 & $0.089^{* *}$ \\
\hline protein & 85,44 & 36,26 & 33,5 & 149,93 & 85,01 & 25,51 & 33,59 & 124,4 & 174,38 & 285,07 & 41,27 & 1075 & $0.490^{* * *}$ \\
\hline fat & 84,90 & 30,30 & 43,4 & 155,02 & 75,88 & 27,12 & 44,7 & 125,5 & 93,15 & 26,15 & 30,37 & 126,27 & $0.329 *$ \\
\hline iron & 11,14 & 4,69 & 0,8 & 18,6 & 13,00 & 7,59 & 0,8 & 27,9 & 12,22 & 7,02 & 2,1 & 24,4 & $0.785^{*}$ \\
\hline vit $\mathrm{C}$ & 64,67 & 111,05 & 0 & 364 & 14,75 & 36,67 & 0 & 118 & 9,83 & 34,06 & 0 & 118 & $0.128^{* *}$ \\
\hline Nitrate & 0,08 & 0,29 & 0 & 1 & 0,00 & 0,00 & 0 & 0 & 0,00 & 0,00 & 0 & 0 & $0.368^{\text {*** }}$ \\
\hline total calories & 2581,08 & 753,78 & 1551,32 & 4136,73 & 2274,96 & 440,20 & 1581,96 & 3101,9 & 2459,89 & 334,58 & 1554,73 & 2916,4 & $0.351^{* *}$ \\
\hline
\end{tabular}

Based on the results of the analysis using the One Way ANOVA test and the Kruskal Wallis test of all confounding variables there were no significant differences from the three groups $(p>0.05)$. From the results of the analysis of Table 4.6 from the three groups shows that the intake of nitrate, Vit $\mathrm{C}$, and iron which is lacking, this is influenced by the consumption patterns that consume less vegetables or fruits, in addition to the habit of eating fast food which is more in demand by athletes because it is easy in the manufacturing process, so the intake of nitrates, Vit $\mathrm{C}$ is very less. So that the intake of nitrate, Vit $\mathrm{C}$ and also iron is mostly only obtained from the consumption of beetroot juice during the administration of the intervention. 


\section{DISCUSSION}

Proper nutrition is the main basis for an athlete's prime performance when competing, nutrition is also needed to repair or replace damaged body cells [20]. The most frequently consumed foodstuffs are instant noodles and processed meats such as meatballs, high-calorie food items but lacking nutritional value, while the optimal performance of athletes must meet the adequacy of macro and micronutrients so that during interventions it can be said that micronutrients are primary substances iron, folic acid and vitamin $\mathrm{C}$ which are theoretically known to increase hemoglobin levels are mostly only obtained from beetroot and certainly contribute most to athlete hemoglobin levels. The results of this study provide a different picture from the results of research conducted by Dieny, et al. [4] conducted in 18 UNNES Football Club athletes aged 18-22 years, beetroot juice given for 7 days and concluded there was no significant effect from beetroot juice administration is done to increase the value of Hemoglobin, but this can occur because of the length of the intervention which is only 7 days and a relatively smaller number of samples because in several other studies prove that beetroot contributes to improving hemoglobin levels in the blood, such as the results research conducted by Anggraini et al. [21] by providing beetroot juice therapy in adolescents with anemia for 7 days, obtained significant results on increasing hemoglobin levels after beetroot juice therapy.

The post-test measurement of the VO2Max value was carried out on the 16th day after the intervention for 15 consecutive days. The VO2Max measurement test was carried out twice, namely at the beginning before giving the intervention and on the 16th day after giving the intervention for 15 days. Cardiovascular endurance (VO2Max) values in 3 groups each experienced a significant increase, but the highest increase in VO2Max value was in the group that was given the intervention of $300 \mathrm{ml}$ beetroot juice. The value obtained is in the group with the intervention of $300 \mathrm{ml}$ beetroot juice the average VO2Max value before the intervention is $43.69 \mathrm{ml} / \mathrm{kg} /$ minute and after the intervention, it becomes an average of $49.39 \mathrm{ml} / \mathrm{kg} / \mathrm{minute}$. In the $200 \mathrm{ml}$ group, VO2Max values averaged before $39.85 \mathrm{ml} / \mathrm{kg} / \mathrm{min}$ and after the intervention averaged $43.57 \mathrm{ml} / \mathrm{kg} / \mathrm{min}$. The control group VO2Max initial value averaged $38.53 \mathrm{ml} / \mathrm{kg} / \mathrm{min}$ and after an average of $41.26 \mathrm{ml} / \mathrm{kg} / \mathrm{min}$. The increase in VO2Max value was due to an increase in hemoglobin levels and high nitrate content in beetroot given during the intervention. Vegetables provide more than 80 percent of nitrate intake, while based on recall 24 obtained by almost all athletes in the three groups studied do not have the habit of consuming vegetables, other than because there are no eating arrangements, fast food is more attractive to athletes because it is easy in the manufacturing process, thus nitrates and the positive effects that occur during the intervention are only obtained from beetroot juice given.

Nitrates in the body will be converted into nitrogen monoxide (NO), which is a chemical that can activate other chemicals in the process of vasodilation of blood vessels caused by the relaxation of smooth muscle cells in the walls of arteries and veins. When blood vessels dilate, blood circulation will increase and increase cardiac output. Vasodilation of blood vessels also determines the distribution of oxygen in the blood can be distributed throughout the body optimally, this prevents fatigue and muscle cramps as well as various other risks of sports injuries, in other words, the high nitrate content in beetroot juice is capable of increasing the athlete's VO2Max which biologically affects the regulator utilization of $\mathrm{O} 2$ by muscle contractors so that the distribution of $\mathrm{O} 2$ according to muscle requirements and nitrate supplementation until the 15th day can increase mitochondrial mass so that it also increases the use of NO (Nitric oxide) in the mitochondria in producing energy [22], therefore, the recommended duration of beetroot extract is more than 15 days for endurance athletes such as badminton athletes.

Increased hemoglobin levels also play a role in increasing the value of VO2Max, the adequacy of protein in the blood that functions as a carrier of oxygen to all body tissues allows an increase in the capacity of VO2Max athletes. The iron that is in each hemoglobin molecule is very important in carrying out its function in binding and releasing oxygen.

The results of this study are in line with research conducted by Bailey et al. [14] which states that beetroot can increase VO2Max in the subject of 8 healthy men (not athletes) aged 19-38 years after consuming $500 \mathrm{ml}$ of beetroot/day for 6 days, also relevant to from the results of research Vanhatalo et al. [22] after the intervention of beetroot extract 500 $\mathrm{ml} /$ day in 8 athletes continued from 5 days to 15 days, VO2Max treatment group increased significantly compared to the control group, it can be concluded that beetroot juice gave a significant effect large endurance measured with a significant increase in the measurement of VO2Max values and according to the results of previous studies, this does not only apply to athletes but also to non-athletes who routinely consume beetroot juice.

It has been described in several previous theories that the better the value of maximal oxygen uptake will allow the athlete to be able to do his sports activities longer. Especially in aerobic sports, excellent VO2Max conditions will certainly produce excellent endurance or endurance. These conditions will certainly benefit athletes. Puype et al. [23], conducted on 11 athletes, states that the optimal dose of nitrate that is indicated to increase plasma nitrite is between 5 - 8 mmol of nitrate contained in $500 \mathrm{ml}$ of beetroot juice. The dose is given more than three times a day ie $1.7 \mathrm{mmol}$ nitrates each at breakfast, lunch and at dinner, and given 2-3 hours before exercise. This dosage can optimize the nitrate - nitrite - 
NO pathway by increasing plasma nitrite so that it can improve the efficiency of oxygen use during training and increase tolerance to fatigue when exercising in conditions of oxygen deprivation, although in this study athletes were only given a dose of $300 \mathrm{ml}$ and $200 \mathrm{ml}$ at a time consumption before exercise for 15 days, it was enough to give a significant increase in hemoglobin levels, especially in the athlete's VO2Max value.

The contribution of various confounding variables one of which is calorie intake, energy, carbohydrate, protein, fat, iron, vitamin $\mathrm{C}$ and nitrate apart from beetroot in research statistically there is no effect on changes in hemoglobin levels or VO2Max values of badminton athletes in all three groups, and based on the results of the analysis there were no significant differences between the confounding variables in the three groups.

\section{CONCLUSION}

There were significant differences in hemoglobin levels in badminton athletes after consuming beetroot juice, the $200 \mathrm{ml}$ beetroot juice group $(\mathrm{p}=0.001)$, the $300 \mathrm{ml}$ beetroot juice group $(\mathrm{p}=0.002)$. There was a difference in the levels of Hemoglobin in badminton athletes after the treatment between consuming $200 \mathrm{ml}$ beetroot juice and the group consuming $300 \mathrm{ml}$ beetroot juice but it was not significant $(\mathrm{p}=0.744>\mathrm{p}=0.05)$. There was a significant difference in VO2Max value after consumption of beetroot juice in the $300 \mathrm{ml}$ group $(\mathrm{p}=0,000)$, but there were no significant differences in the VO2Max value in the control group $(\mathrm{p}=0.007)$ and the $200 \mathrm{ml}$ group $(\mathrm{p}=0.007)$. There was a significant difference in the value of VO2Max badminton athletes between the group consuming $200 \mathrm{ml}$ beetroot juice and the group consuming $300 \mathrm{ml}$ beetroot juice after treatment $(\mathrm{p}=0.031<\mathrm{p}=0.005)$.

\section{REFERENCES}

1. Hasan, S. (2008). Kesegaran Jasmani Atlet Sepak Bola Pra-Pubertas. Jurnal Iptek Olahraga, 10(3), $188-202$.

2. Maqsalmina, M. (2007). Pengaruh Latihan Aerobik Terhadap Perubahan Vo2 Max Pada Siswa Sekolah Sepak Bola Tugu Muda Semarang Usia 12-14 tahun (Doctoral dissertation, Faculty of Medicine).

3. Irawan, M.A. (2007). Metabolisme Energi Tubuh \& Olahragawan. Sport Science Brief, 1(7).

4. Dieny, F.F., Fitranti, D.Y., Panunggal, B. and Safitri, I. (2017). Pengaruh pemberian jus umbi bit (beta vulgaris) terhadap kadar Hemoglobin dan performa atlet sepak bola. Jurnal Gizi Indonesia (The Indonesian Journal of Nutrition), 5(2), pp.119-126.

5. Jelalian, E. and Steele, G. (2008). Childhood and Adolescent Obesity. Springer.

6. Hagberg, J. M., Moore, G. E., \& Ferrell, R. E. (2001). Specific genetic markers of endurance performance and VO2max. Exercise and sport sciences reviews, 29(1), 15-19.

7. Haas, J.D. and Brownlie IV, T. (2001). Iron deficiency and reduced work capacity: a critical review of the research to determine a causal relationship. The Journal of nutrition, 131(2), pp.676S-690S.

8. Putri, E.B.A., Wirjatmadi, R.B., \& Adriani, M. (2012). Pengaruh Suplementasi Besi Dan Zinc Terhadap Kadar Hb Dan Kesegaran Jasmani Remaja Putri Yang Anemia Defisiensi Besi. The Indonesian Journal of Public Health, 9(1), pp.67-76.

9. Gibson, R.S. (2005). Principles of nutritional assessment. Oxford university press, USA.

10. Beard, J., \& Tobin, B. (2000). Iron status and exercise. The American journal of clinical nutrition, 72(2), 594S-597S.

11. Huldani. (2010). Pengaruh Kadar Hemoglobin dan Jenis Kelamin Terhadap Konsumsi Oksigen Maksimum Siswasiswi Pesantren darul Hijrah, 509-511.

12. Dieny, F.F., Fitranti, D.Y., Panunggal, B., \& Safitri, I. (2017). Pengaruh pemberian jus umbi bit (beta vulgaris) terhadap kadar Hemoglobin dan performa atlet sepak bola. Jurnal Gizi Indonesia (The Indonesian Journal of Nutrition), 5(2), pp.119-126.

13. Safitri, I., \& Dieny, F.F. (2015). Pengaruh Jus Umbi Bit (Beta Vulagaris) Terhadap VO2Max Atlet Sepak Bola (Doctoral dissertation, Diponegoro University).

14. Bailey, S.J., Winyard, P., Vanhatalo, A., Blackwell, J.R., DiMenna, F.J., Wilkerson, D.P., Tarr, J., Benjamin, N. and Jones, A.M. (2009). Dietary nitrate supplementation reduces the O2 cost of low-intensity exercise and enhances tolerance to high-intensity exercise in humans. Journal of applied physiology, 107(4), 1144-1155.

15. Bailey, S.J., Winyard, P., Vanhatalo, A., Blackwell, J.R., DiMenna, F.J., Wilkerson, D.P., Tarr, J., Benjamin, N. and Jones, A.M. (2009). Dietary nitrate supplementation reduces the $\mathrm{O} 2$ cost of low-intensity exercise and enhances tolerance to high-intensity exercise in humans. Journal of applied physiology, 107(4), 1144-1155.

16. Cermak, N.M., Gibala, M.J. and Van Loon, L.J. (2012). Nitrate supplementation's improvement of 10-km time-trial performance in trained cyclists. International journal of sport nutrition and exercise metabolism, 22(1), 64-71.

17. Christensen, P.M., Nyberg, M. and Bangsbo, J. (2013). Influence of nitrate supplementation on VO2 kinetics and endurance of elite cyclists. Scandinavian journal of medicine \& science in sports, 23(1), e21-e31.

18. Jones, A.M., (2014). Dietary nitrate supplementation and exercise performance. Sports medicine, 44(1), 35-45.

19. Stang. (2014). Cara Praktis Penentuan Uji Statistik Dalam Penelitian Kesehatan dan Kedokteran. Jakarta: Mitra Wacana Media.

20. Arimbi, A., Rahman, A., \& Saharullah, S. (2018). Pengaturan nutrisi tepat bagi atlet. In Seminar Nasional 
Pengabdian Kepada Masyarakat, (6).

21. Anggraini, D.D. and Saragita, N. 2019. Pengaruh Pemberian Jus Buah Bit Terhadap Kenaikan Kadar Hb Pada Ibu Hamil Trimester III. Jurnal Darul Azhar Vol. 8 No. 1.

22. Vanhatalo, A., Bailey, S. J., Blackwell, J. R., DiMenna, F. J., Pavey, T. G., Wilkerson, D. P., ... \& Jones, A. M. (2010). Acute and chronic effects of dietary nitrate supplementation on blood pressure and the physiological responses to moderate-intensity and incremental exercise. American Journal of Physiology-Regulatory, Integrative and Comparative Physiology, 299(4), R1121-R1131.

23. Puype, J., Ramaekers, M., Van Thienen, R., Deldicque, L., \& Hespel, P. (2015). No effect of dietary nitrate supplementation on endurance training in hypoxia. Scandinavian journal of medicine \& science in sports, 25(2), pp.234-241. 